This is the final peer-reviewed accepted manuscript of:

Piarulli S, Scapinello S, Comandini P, Magnusson K, Granberg M, Wong JXW, Sciutto G, Prati S, Mazzeo R, Booth AM, Airoldi L (2019) Microplastic in wild populations of the omnivorous crab Carcinus aestuarii: $A$ review and a regional-scale test of extraction methods, including microfibres. Environmental Pollution 251, 117-127. DOI: 10.1016/j.envpol.2019.04.092

The final published version is available online at:

https://doi.org/10.1016/i.envpol.2019.04.092

Rights / License:

The terms and conditions for the reuse of this version of the manuscript are specified in the publishing policy. For all terms of use and more information see the publisher's website.

This item was downloaded from IRIS Università di Bologna (https://cris.unibo.it/)

When citing, please refer to the published version. 


\title{
Microplastic in wild populations of the omnivorous crab Carcinus aestuarii: A review and a regional-scale test of extraction methods, including microfibres
}

\author{
Stefania Piarulli ${ }^{\text {a, * }}$, Sara Scapinello ${ }^{\text {a }}$, Paolo Comandini ${ }^{a}$, Kerstin Magnusson ${ }^{c}$, Maria Granberg ${ }^{c}$, \\ Joanne X.W. Wong ${ }^{a}$, Giorgia Sciutto ${ }^{b}$, Silvia Prati ${ }^{b}$, Rocco Mazzeo ${ }^{b}$, Andy M. Booth ${ }^{d}$, Laura Airoldi ${ }^{a, * *}$

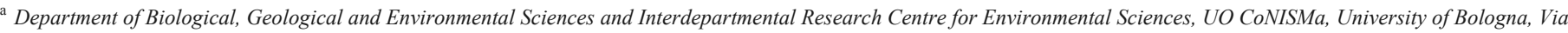 \\ S. Alberto 163, 48123, Ravenna, Italy \\ b Department of Chemistry "G.Ciamician”, University of Bologna, Via Guaccimanni 42, 48121, Ravenna, Italy \\ c IVL Swedish Environmental Research Institute, Kristineberg 566, SE45178, Fiskebäckskil, Sweden \\ ${ }^{d}$ SINTEF Ocean, Department of Environmental and New Resources, Brattørkaia 17 C, 7010, Trondheim, Norway \\ * Corresponding author.THMDOIDSIDXCO \# XQIERIW \\ ** Corresponding author.LOXUDDLROA\# XQLERIIW
}

\begin{abstract}
\$ EWMFW
Microplastic (MP) has become ubiquitous in the marine environment. Its threat to marine organisms has been demonstrated under laboratory conditions, yet studies on wild populations still face methodological difficulties. We reviewed the methods used to separate MP from soft animal tissues and highlighted a lack of standardised methodologies, particularly critical for synthetic microfibres. We further compared enzymatic and a potassium hydroxide (KOH)-based alkaline digestion protocols on wild crabs (Carcinus aestuarii) collected from three coastal lagoons in the north Adriatic Sea and on laboratory-prepared synthetic polyester (PES) of different colour and polypropylene (PP). We compared the cost-effectiveness of the two methods, together with the potential for adverse quantitative or qualitative effects on MP that could alter the capability of the polymers to be recognised via microscopic or spectroscopic techniques. Only $5.5 \%$ of the 180 examined crabs contained MP in their gastrointestinal tracts, with a notably high quantitative variability between individuals (from 1 to 117 particles per individual). All MP found was exclusively microfibres, mainly PES, with a mean length $( \pm \mathrm{SE}$ ) of $0.5 \pm 0.03 \mathrm{~mm}$. The two digestion methods provided comparable estimates on wild crabs and did not cause any visible physical or chemical alterations on laboratory-prepared microfibres treated for up to 4 days. $\mathrm{KOH}$ solution was faster and cheaper compared to the enzymatic extraction, involving fewer procedural steps and therefore reducing the risk of airborne contamination. With digestion times longer than 4 days, KOH caused morphological alterations of some of the PES microfibres, which did not occur with the enzymatic digestion. This suggests that $\mathrm{KOH}$ is effective for the digestion of small marine invertebrates or biological samples for which shorter digestion time is required, while enzymatic extraction should be considered as alternative for larger organisms or sample sizes requiring longer digestion times.
\end{abstract}

Keywords: Microplastic $\square$ Microfibres $\square$ Potassium hydroxide $\square$ Enzymes $\square$ Digestion $\square$ Crab

\section{Introduction}

Marine plastic pollution has become a matter of increasing concern because of its ubiquitous presence and worldwide distribution (Carbery et al., 2018), from polar regions to the equator (Barnes et al., 2009). Plastic contamination may represent a threat to wildlife, with considerable economic impacts on fisheries and potential consequences for human health (Van Cauwenberghe and Janssen, 2014). Owing to their small dimensions $(<5 \mathrm{~mm})$, microplastic (MP) particles overlap in size range with natural organic matter and plankton, and consequently have been shown to be ingestible by a wide range of marine species from different trophic levels (Wright et al., 2013), including zooplankton, polychaetes, bivalves, crustaceans, demersal and pelagic fish, seabirds, reptiles and mammals (Codina-García et al., 2013; Cole et al., 2013, 2014; Courtene-Jones et al., 2017b; De Witte et al., 2014; Lusher et al., 2013, 2015; Nelms et al., 2018; Tourinho et al., 2010; Van Cauwenberghe et al., 2015; Van Cauwenberghe and Janssen, 2014; Watts et al., 2015). Once ingested, MP can have physical, chemical and biological impacts on biota (Aljaibachi and Callaghan, 2018; Capolupo et al., 2018; Setälä et al., 2014; Straub et al., 2017; Wright et al., 2013) either directly or as a consequence of the associated additives and contaminants (Batel et al., 2018; Mato et al., 2001; Sleight et al., 2017; Teuten et al., 2009).

To date, most studies on the ingestion and transfer of MP have been performed under laboratory conditions, often exposing organisms to non-natural concentrations (Besseling et al., 2013; Cole et al., 2013; Von Moos et al., 2012; Watts et al., 2014). To gain a clear understanding of MP availability to marine organisms, the potential for MP accumulation and transfer through the food webs, and the risks for marine ecosystems and associated ecological processes, it is fun- 
damental to obtain accurate measures of MP distributions in wild populations. Such information is currently limited, particularly in benthic invertebrate food webs. In part, this can be attributed to a lack of harmonisation of unit reports and extraction protocols that makes different studies not comparable. Many scientists and policy institutes highlighted a need of standardisation of methods and unit measures (Catarino et al., 2017; Panel and Chain, 2016; Unep, 2009). However, standard methods can be difficult to establish as MP may originate from a wide variety of sources (Andrady, 2011; Barnes et al., 2009; Boucher and Friot, 2017; Browne et al., 2011; Napper and Thompson, 2016; Unep, 2009), and usually show high heterogeneous physical-chemical properties (e.g. size, shape, colour, density, and chemical composition) (Browne et al., 2008, 2011; Cole et al., 2011; Karlsson et al., 2017; Wright et al., 2013). Moreover, the very long multi-step approach (Iso, 2018) that standard organisation (such as ISO or OECD) usually take to standardise and accept methods makes particularly difficult the selection of a single method to monitor the microplastic contamination in marine organisms. A more feasible action would be to select a range of methods that minimise the risk of over/underestimation of synthetic particles and could be widely use for the same typologies of samples.

Different extraction methods may variously affect the morphology and chemistry of different MP types, making comparison of results challenging (Dehaut et al., 2016). One of the most critical procedural steps is to achieve an appropriate separation of MP from biological tissues without changing the physical-chemical properties of the particles. This is typically done via digestion of the tissue followed by filtration of the digestate. Various methods for tissue digestion are available, including acids such as $\mathrm{HCl}, \mathrm{HNO}_{3}, \mathrm{HClO}_{4}$ (Claessens et al., 2013; De Witte et al., 2014), bases such as $\mathrm{NaOH}, \mathrm{KOH}$ (Claessens et al., 2013; Dehaut et al., 2016; Rochman et al., 2013), hydrogen peroxide (Avio et al., 2015a,b) and enzymes (Catarino et al., 2017; Cole et al., 2014). A recent study by Kühn et al. (2017) suggested that $1 \mathrm{M}$ potassium hydroxide $(\mathrm{KOH})$ offers a good compromise between maximising tissue digestion efficiency and minimising damage to polymeric structures. Although this method has been used in several studies to monitor the occurrence of MP in the gastrointestinal tract of organisms, the effects of this strong base on MP properties remain unclear, particularly for polymers commonly used to produce microfibres (e.g. polyester, polyamide and polyacrylate).

The physical-chemical properties of MP can be extremely variable in coastal and marine areas, significantly influencing their environmental fate and effects. Reliable and robust approaches for extracting and characterising MP are fundamental to understand how they enter the marine environment and their dynamics at community and ecosystem levels. An optimised extraction method should permit an accurate estimate of MP abundance without affecting the key MP physical-chemical properties needed to assess their occurrence and distribution. Currently, there is insufficient information to identify a universal digestion protocol for biological tissues, with the different methods reported in the literature needing more detailed comparison and assessment to identify the most effective solution.

The current study reviews the available knowledge on the effectiveness of different digestion approaches for extracting MP from biological samples and their potential impacts on the physical-chemical properties of MP. The review has a particular focus on field collected organisms and synthetic microfibers. The relatively novel enzymatic and the most established alkaline $\mathrm{KOH}$ digestion method resulted particularly promising in terms of effectiveness and low impact on pristine polymers. However, information on the effectiveness and effects of these methods on naturally ingested and weathered MP is still scarce. Thus, using the available literature as a basis, the two digestion procedures were directly compared for their effectiveness in digesting soft tissue, cost and applicability to the study of MP ingested by wild organisms naturally exposed to MP. The selected test species was the omnivorous shore crab Carcinus aestuarii. This crab is a common inhabitant of the northern Adriatic coastal lagoons (Mistri et al., 2001). Such estuarine environments can exhibit high MP pollution (Vermeiren et al., 2016) originating from terrestrial run-off, wastewater discharges, aquaculture, fishing, and other anthropogenic sources (Vianello et al., 2013). C. aestuarii is an omnivore scavenger and chief predator, feeding on a variety of animal and plant sources (Mistri, 2004), making the species potentially vulnerable to high MP pollution. Studies on the congeneric species C. maenas have suggested that ingested MP particles can be retained for long periods ( $>2$ weeks) by the hair-like setae in the gut, and retention could be even longer for microfibres (Watts et al., 2015). As a result, C. aestuarii may also play a critical role in the transfer of MP to higher trophic levels, including high-market-value fish species such as the gilthead seabream Sparus aurata, the sea bass Dicentrarchus labrax, and the European eel Anguilla Anguilla, which commonly prey on this crab (Özbek et al., 2012).

We evaluated the occurrence and characteristics of MP in field-collected crabs using the two different methods (enzymatic and alkaline $\mathrm{KOH}$ ) and assessed any adverse side-effects of each method that could alter the reliability of MP to be recognised or quantified. Since the evaluation of potential adverse effects of the two digestion methods on synthetic microfibres resulted particularly scarce in literature, the physical-chemical effects of the two selected digestion methods on this class of MP were further compared.

\section{Material and methods}

\subsection{Literature review}

A review of the available literature was conducted on the effectiveness of digestion protocols to separate synthetic plastic particles from biological material, mainly represented by soft tissues. Only peer-reviewed articles that explicitly provided information on the effectiveness of the methods and the relative effects on MP morphology and/ or chemistry were selected. Literature not accounting for the effects of digestion methods on at least shape, origin, or polymer type were excluded. The search was performed on Web of Science Core Collection, using the following search terms: "Microplastic", "Digestion", "Biota" combined using the Boolean operator 'AND'. The bibliographic research resulted in 56 original peer-reviewed research articles from 1985 to 2018. A total of 11 articles focusing on different digestion methods used to isolate MP particles from both marine and fresh water biota were retained as the basis for the review.

Subsequently two methods, enzymatic and alkaline with $\mathrm{KOH}$, which seemed the most effective in digesting organismal soft tissue with limited adverse effects on a wide range of polymers were selected and tested on both wild specimens and laboratory trials.

\subsection{Study area}

The northern Adriatic coast of Italy is fringed by a lagoon-river delta system with moderate exposure to wave action and a semi-diurnal micro-tidal regime (Russo et al., 2002). The numerous transitional water bodies and adjoining coasts in this region are intensively employed for multiple activities, with impacts from intensive farming and aquaculture, industry, dense urban centres in the watershed, shipping and tourism (Airoldi et al., 2016; Lo et al. 2017). The limited 
data available suggest considerable MP pollution in these systems (Vianello et al., 2013).

To explore the possible effects of the two digestion methods on a wide range of MP typologies, C. aestuarii we sampled from three coastal lagoons with different environmental conditions (hydrodynamics, wave exposure, nutrient loading, sediment granulometry) and varying pressures from potential anthropogenic sources of MP pollution (industries, aquaculture and wastewater effluents). From south to north, the lagoons were:

1. Piallassa Baiona $\left(44^{\circ} 28^{\prime} 26.6^{\prime}, ; 12^{\circ} 14^{\prime} 52.5^{\prime \prime} \mathrm{E}\right)$. This lagoon is divided into several ponds connected to the sea by channels, and receives inputs from 6 wastewater channels from urban, agricultural, industrial sewage treatment plants and thermal power plants (Airoldi et al., 2016).

2. Sacca di Bellocchio nature reserve (44³8'01.97', $\left.12^{\circ} 15^{\prime} 48.78^{\prime \prime \prime} \mathrm{E}\right)$ in the Parco Delta del Po dell'Emilia-Romagna $\left(44^{\circ} 37^{\prime} 39.8^{\prime \prime} \mathrm{N}, 12^{\circ} 15^{\prime} 55.8^{\prime \prime} \mathrm{E}\right)$. This is a back-barrier lagoon connected to the sea by a channel maintained by dredging (Wong et al., 2015). It is a protected area where the limited human pressures relate mainly to seasonal tourism and recreational activities.

3. Chioggia lagoon $\left(45^{\circ} 13^{\prime} 11.52^{\prime}\right.$ '; $\left.12^{\circ} 16^{\prime} 44.45^{\prime \prime \prime} \mathrm{E}\right)$. This lagoon is located in the southern part of the Venice Lagoon. It is an area characterised by intensive fishing and aquaculture, which may present a potential source of MP pollution.

\subsection{Crab sample collection and dissection}

Sampling was performed in June 2016. At each lagoon, C. aestuarii individuals were collected using seven standard fish traps prepared with fresh fish bait. The traps were deployed partially submerged approximately $10-100 \mathrm{~m}$ apart over mudflat areas. Each deployment lasted for $2 \mathrm{~h}$. All crabs captured were retained from the traps, stored individually and transported to the laboratory where they were frozen at $-20^{\circ} \mathrm{C}$.

One hundred and eighty crabs having the same carapace size range $(3-5 \mathrm{~cm}$ in width) were further dissected to remove the soft gastrointestinal tract tissue. The gastrointestinal tracts were weighed and placed in individual acid-washed and Milli-Q water-rinsed glass beakers for further processing.

\subsection{Digestion of the soft gastrointestinal tissue}

Half of the crabs from each lagoon $(n=30)$ were treated with the enzymatic procedure and half with the alkaline $(\mathrm{KOH})$ procedure, resulting in a total of 90 crabs being analysed with each method. The enzymatic digestion protocol originally developed by Löder et al. (2017) for the analysis of planktonic samples was simplified (involving less procedural steps and enzymes) for use on the gastrointestinal tract of crabs. The protocol used Biozym F (lipase) and Biozym SE (protease and amylase) produced by Spinnrad ${ }^{\circledR}$ (Bad Segeberg, Germany) combined with a preceding detergent step using sodium dodecyl sulphate (SDS). The enzymes, differently from Löder et al. (2017), were in the form of common laundry detergents, therefore being relatively cheap and with longer durability compared to technical enzymes. Ten $\mathrm{mL}$ of the $25 \%$ anionic detergent sodium dodecyl sulphate $\left(250 \mathrm{~g} \mathrm{SDS} \mathrm{L}^{-1}\right)$ $\left(\right.$ Sigma-Aldrich $\left.{ }^{\circledR}\right)$ was added to each gastrointestinal tract sample immediately after dissection and samples were left to incubate at $50^{\circ} \mathrm{C}$ for $24 \mathrm{~h}$. Subsequently, $5 \mathrm{~mL}$ of Enzyme $\mathrm{F}$ and $5 \mathrm{~mL}$ of Enzyme SE $\left(\right.$ Spinnrad $\left.^{\circledR}\right)$ were added. Samples were gently shaken and incubated at room temperature for $48 \mathrm{~h}$. Five $\mathrm{mL}$ of Milli-Q water was added to samples with a high viscosity allowing for proper filtration of the digestate.
The alkaline digestion was performed using $1 \mathrm{M} \mathrm{KOH}$ according to Kühn et al. (2017), with $20 \mathrm{~mL}$ of the $\mathrm{KOH}$ solution added to each gastrointestinal tract sample. Vials were covered and incubated for $48 \mathrm{~h}$ at room temperature without any further manipulation until filtration. Finally, samples treated with both methods were individually vacuum filtered onto nylon filters (mesh size: $20 \mu \mathrm{m}, \varnothing: 5 \mathrm{~cm}$, PLASTOK $^{\circledR}$ ), and dried at room temperature on covered glass petri dishes.

\subsection{Microplastic quantification and identification}

The material retained on each filter was visually inspected under a stereomicroscope (Leica microsystem, 50X magnification). Particles were manipulated with stainless steel tweezers to identify and thus exclude non-plastic particles such as glass, sand, mineral and shell. Particles exhibiting an obvious cellular structure were excluded as organic material. Any particle visually identified as being potentially made of plastic was characterised (shape, colour, size at the largest cross section), photographed (using a microscope mounted camera Motic BTWB, with Motic 2.0 software). Particles were then retained separately for subsequent Fourier-Transform-Infrared (FTIR) analysis using a Nicolet iN ${ }^{\mathrm{TM}} 10 \mathrm{MX}$ imaging microscope (Thermo Fisher Scientific, Waltham, MA, USA), fitted with a mercury-cadmium-telluride detector cooled by liquid nitrogen. Measurements were performed using a slide-on Attenuated Total Reflectance (ATR) objective, equipped with a conical germanium crystal, in the range $4000-675 \mathrm{~cm}^{-1}$, at a spectral resolution of $4 \mathrm{~cm}^{-1}$. OMNIC PictaTM (Thermo Fisher Scientific, Waltham, MA, USA) was applied for a combined manipulation of the spectra dataset. Confirmation of polymer molecular signals in the recorded spectra was achieved by using the internal OMNIC Picta ${ }^{\mathrm{TM}}$ database, where similarities in wavenumber position and relative intensities of absorption bands were evaluated and compared.

\subsection{Contamination prevention and quality control procedures}

MP, particularly microfibres, are ubiquitous in indoor environments where they are present in the air and deposited on surfaces. Their presence can lead to contamination of samples and subsequent inaccuracies in results and bias. In addition, the low abundances of MP present within many environmental samples means any particle loss occurring during processing can potentially result in underestimation of MP occurrence and distributions. To counteract these issues the measures listed below were applied at each procedural step from sampling through to final analyses.

\subsubsection{Sample collection}

The use of plastic materials was reduced to a minimum by using metal and glass equipment where possible. All equipment was acidic Milli-Q washed and covered with aluminium foil prior to use. People collecting samples wore natural fibre clothing. All synthetic materials used at this stage were recorded (e.g. colour, polymer type) to enable potential contamination sources to be traced.

\subsubsection{Sample processing}

Sample processing (digestion and filtration) was carried out in a clean laboratory. All laboratory surfaces and floors were vacuum-cleaned and wiped with filtered detergent prior to use. To prevent external contamination, air circulation was minimised and a restricted number of personnel were allowed to enter in the laboratory.

Organisms were rinsed with Milli-Q water prior dissection to remove any residual external plastic particles. Contact with air and plastic surfaces during all laboratory procedures was minimised for 
samples, instruments and reagents by covering them with Milli-Q rinsed aluminium foil before and after use. All instrumentation and equipment, including filters, was cleaned using bio-detergent and rinsed thoroughly with Milli-Q water prior to use. Four air filters were placed in various locations in the laboratory to monitor potential airborne contamination during sample processing. To validate the effectiveness of the preventive practices and to test for potential differences in contamination risks between the two digestion methods, 4 procedural blanks, treated identically to the samples, were performed for each batch of samples processed. Material retained on air filters and from the procedural blanks was carefully examined following the same procedure as for the biological samples (see Section 2.5) to identify any synthetic particles representing external contamination and which should be accounted for using a blank correction.

To limit the risk of losing particles during the extraction procedures, crabs were carefully dissected without breaking the whole gastrointestinal tract, which was immediately placed into a glass beaker. The homogenisation of the samples in the digestion solution was conducted by slowly shaking the digestate only. After filtration of the digestate, each beaker and the filtering apparatus was rinsed 3 times with Milli-Q water to ensure that all particles stuck on the beaker walls were transferred to the filter.

\subsubsection{Filter inspection}

To minimise the risk of contamination during the visual inspection step, filters were exposed to the ambient air for the least amount of time possible. Inspection for microfibres, which are prone to contaminate samples due their ubiquitous presence in indoor air, was carried out first before inspection for other particle shapes (e.g. fragments, films, pellets). To minimise the risk of underestimating the number of plastic particles, two trained people inspected all filters and in the case of doubt regarding composition (synthetic or natural) the item was always selected for analysis by FTIR.

\subsubsection{Non-synthetic microfibres}

A goal of the digestion method comparison study was to provide an estimate for the potential risk of airborne contamination of samples related to the two different approaches. As the measures to prevent MP contamination were successful, the number of non-synthetic anthropogenic microfibres originating from clothing (e.g. laboratory coats), for which no preventative measures were applied, was used as an alternative estimate. Non-synthetic microfibres were counted on both air filters and in procedural blanks. A subsample of the most frequently occurring non-synthetic microfibres was analysed via FTIR to validate their composition and origin.

\subsection{Digestion methods tested on synthetic microfibres}

To determine if the digestion methods used may have influenced the results through physical-chemical alteration of the plastic microfibres during the treatment, additional tests were carried out using laboratory-prepared known microfibres of common synthetic materials found in the marine environment and in the gut of marine organisms: PES of different colours and PP. Microfibres $(\sim 5 \mathrm{~mm})$ of each polymer type were cut from known fabrics or other plastic materials and placed in individual $20 \mathrm{~mL}$ glass scintillation vials. The microfibres were exposed in triplicate to both extraction methods for a total of 7 days. This long exposure time was chosen to explore whether either method could be applied without any time restrictions, therefore making them relevant for application to organisms needing extended exposures to the digestion agent.
As microfibres treated with $\mathrm{KOH}$ showed signs of physical alteration (see Results section), an additional experiment was performed to investigate if the rate of microfibre degradation changes over time (samples analysed after 1, 2, 3, 4, 7 days of exposure).

For all tests, untreated microfibres of each polymer type were used as controls. Microfibres were inspected and photographed under a stereomicroscope before and after the treatments. Any qualitative morphological effects were evaluated following the protocol developed by (Enders et al., 2017) with L0 corresponding to no change (or unaffected), L1: initial recognizable changes (e.g. colour, morphology), L2: changes and early stage of dissolution (or disintegration), L3: degradation and change of bulk structure, and L4: indicating complete dissolution (or disintegration). Microfibres (controls and treated) were also analysed using FTIR to identify any chemical alteration in the polymer structure due the digestion treatments.

\subsection{Statistical analyses}

Owing to the large number of individual $C$. aestuarii which contained no MP (0MP), the generated data did not meet the criteria for parametric statistics (Shapiro-Wilk normality test and Fligner-Killeen homogeneity test p-values <0.05). Therefore, the Mann-Whitney-Wilkoxon test was used to compare differences in gastrointestinal MP abundances between crabs digested with the enzymatic $(n=90)$ and alkaline methods $(n=90)$. No blank correction was applied, as air filters and procedural blanks showed no MP contamination (see Results). Differences in external contamination between the two methods were compared by quantifying the non-synthetic anthropogenic microfibres present on the air filters $(n=40$ and $n=36$ for enzymatic and $\mathrm{KOH}$ air filters, respectively) and procedural blank filters $(\mathrm{n}=20)$ with a $t$-test. These data were normally distributed after $\log (\mathrm{x}+1)$ transformation and exhibited homogenous variance (Fligner-Killeen $\mathrm{P}$-value $>0.05$ ). For all tests, the level of significance was set to $<0.05$. All analyses were performed with Rstudio 0.99 .903 (R Core Team, 2016).

\section{Results}

\subsection{Review of the digestion methods}

The most critical aspect of digestion methods used to determine MP distributions in biological samples is to ensure an optimal balance between removal of any biological matrix (which could mask MP identification by e.g. FTIR or Raman spectroscopy) and minimising alteration of MP physical-chemical properties. A review of the existing literature highlighted the common use of strong oxidising agents that can alter the physical-chemical structure of MP, particularly if high temperatures are also employed (Table 1). Acidic methods using nitric or chloric acids $\left(\mathrm{HNO}_{3}, \mathrm{HCl}\right)$ appear to be the most efficient and effective in molecular cleavage and biogenic material dissolution (Claessens et al., 2013; Karami et al., 2017; Naidoo et al., 2017). However, these acid-based methods can be aggressive and may damage pH-sensitive polymers (Catarino et al., 2017; Enders et al., 2017; Van Cauwenberghe and Janssen, 2014). Oxidising agents such as hydrogen peroxide $\left(\mathrm{H}_{2} \mathrm{O}_{2}\right)$ and potassium sulphate $\left(\mathrm{K}_{2} \mathrm{SO}_{4}\right)$ have less effect on polymer properties compared to acids (Avio et al., 2015a,b; Ding et al., 2018; Karami et al., 2017), but can result in incomplete soft tissue digestion and production of foam, which may interfere with the subsequent MP identification (Avio et al., 2015a,b).

Some studies report that strong bases can be a valuable compromise between effective digestion of the biological matrix and limited adverse effects on synthetic particles (Budimir et al., 2018; Catarino 
Table 1

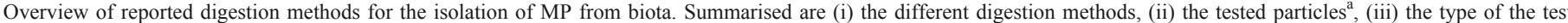

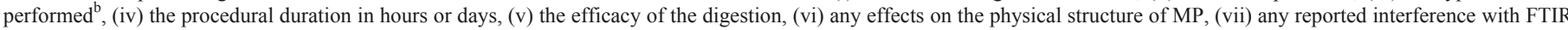
or Raman identification and (viii) the reference. $\mathrm{NP}=$ not performed and $\mathrm{NR}=$ not reported by authors.

\begin{tabular}{|c|c|c|c|c|c|c|c|}
\hline Method & Test particles ${ }^{\mathrm{a}}$ & Test $^{\mathrm{b}} \&$ species & Duration & Efficacy & Physical changes & FTIR/Raman & Reference \\
\hline $\mathrm{HNO}_{3}$ & $\begin{array}{l}\text { Pristine spheres (PS), fibres/fragments } \\
\text { (nylon), industrially made flakes/fragments } \\
\text { (PET, HDPE, PVC); fragments from } \\
\text { consumer products (PP, LDPE, HDPE, PS, } \\
\text { EPS, ABS, PA, PET, PC, PVC, PMMA, } \\
\text { PTFE) }\end{array}$ & $\begin{array}{l}\text { EPR, SPO }(M . \text { edulis } \\
\text { mussel and } C \text {. } \\
\text { garepinius, } A \text {. } \\
\text { dussumieri fish) } \\
\text { FO (A. dussumieri } \\
\text { fish) }\end{array}$ & $2-5 \mathrm{~h}$ & Good & 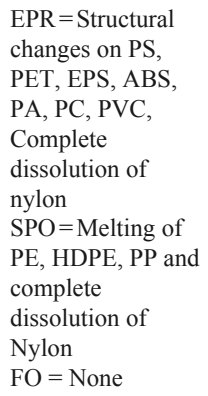 & $\begin{array}{l}\text { Altered } \\
\text { molecular } \\
\text { signals }\end{array}$ & $\begin{array}{l}\text { Catarino } \\
\text { et al. } \\
(2017) \\
\text { Claessens } \\
\text { et al. } \\
\text { (2013) } \\
\text { Enders et } \\
\text { al. (2017) } \\
\text { Karami et } \\
\text { al., 2017 } \\
\text { Naidoo et } \\
\text { al. (2017) }\end{array}$ \\
\hline $\begin{array}{l}\mathrm{HNO}_{3}+ \\
\quad \mathrm{H}_{2} \mathrm{O}_{2}+\mathrm{NaOH}\end{array}$ & $\begin{array}{l}\text { Pristine spheres (PP, PE); fragments from } \\
\text { consumer products (PA, PET, ePS, LDPE) }\end{array}$ & $\begin{array}{l}\mathrm{EPR}, \mathrm{SPO} \text { (various } \\
\text { invertebrates) }\end{array}$ & NR & Good & $\begin{array}{l}\mathrm{EPR}=\text { Degradation } \\
\text { of particles } \\
\mathrm{SPO}=\text { None }\end{array}$ & NR & $\begin{array}{l}\text { Karlsson } \\
\text { et al. } \\
(2017)\end{array}$ \\
\hline $\mathrm{HCl}$ & $\begin{array}{l}\text { Pristine fragments (LDPE, HDPE, PP, PS, } \\
\text { PET, PVC, PA6, PA66) }\end{array}$ & $\begin{array}{l}\text { SPO (C. garepinius } \\
\text { fish) }\end{array}$ & $4 d$ & Good & Melting of PET & $\begin{array}{l}\text { Altered } \\
\text { molecular } \\
\text { signal }\end{array}$ & $\begin{array}{l}\text { Karami et } \\
\text { al., } 2017\end{array}$ \\
\hline $\mathrm{NaClO}$ & $\begin{array}{l}\text { Fragments from consumer products (PP, } \\
\text { LDPE, HDPE, PS, EPS, ABS, PA, PET, } \\
\text { PC, PVC, PMMA, PTFE) }\end{array}$ & EPR & $5 \mathrm{~h}$ & $\begin{array}{l}\text { Formation } \\
\text { of foam }\end{array}$ & None & $\begin{array}{l}\text { Altered } \\
\text { molecular } \\
\text { signals (ABS } \\
\text { and PA) }\end{array}$ & $\begin{array}{l}\text { Enders et } \\
\text { al. }(2017)\end{array}$ \\
\hline VIP1 & $\begin{array}{l}\text { Fragments from consumer products (PP, } \\
\text { LDPE, HDPE, PS, EPS, ABS, PA, PET, } \\
\text { PC, PVC, PMMA, PTFE) }\end{array}$ & EPR & $5 \mathrm{~h}$ & $\begin{array}{l}\text { Presence } \\
\text { of } \\
\text { undigested } \\
\text { material }\end{array}$ & None & NR & $\begin{array}{l}\text { Enders et } \\
\text { al. (2017) }\end{array}$ \\
\hline $\mathrm{H}_{2} \mathrm{O}_{2}$ & $\begin{array}{l}\text { Pristine fragments/beads (LDPE, HDPE, } \\
\text { PP, PS, PET, PVC, PA6, PA66) }\end{array}$ & $\begin{array}{l}\text { SPO (C. gariepinus } \\
\text { fish and mullets) } \\
\text { FO (C. farreri and } M \text {. } \\
\text { galloprovincialis } \\
\text { bivalves; } S \text {. } \\
\text { pilchardus, } S . \\
\text { acanthias, } M . \\
\text { merluccius } \text { fish) }\end{array}$ & $4 d$ & $\begin{array}{l}\text { Foamy } \\
\text { particles } \\
\text { formation }\end{array}$ & None & Good & $\begin{array}{l}\text { Avio et } \\
\text { al., } \\
2015 \mathrm{a}, \mathrm{b} \\
\text { Ding et al. } \\
(2018) \\
\text { Karami et } \\
\text { al., } 2017\end{array}$ \\
\hline $\mathrm{NaOH}$ & $\begin{array}{l}\text { Spheres (ePS), line (nylon), fibres (PES), } \\
\text { pristine fragments/flakes (CA, HDPE, } \\
\text { LDPE, PA-12, PC, PET, PMMA, PP, PS, } \\
\text { PSXL, PTFE, PUR, UPVC, ePS, PA6, } \\
\text { PVC); fragments from consumer products } \\
\text { (PC, PET, HDPE) }\end{array}$ & $\begin{array}{l}\text { EPR, SPO (M. edulis } \\
\text { mussels; } C \text {. harengus } \\
\text { membras fish) } \\
\text { FO (S. sprattus, G. } \\
\text { aculeantus fish) }\end{array}$ & $1 \mathrm{~h}-7 \mathrm{~d}$ & Good & $\begin{array}{l}\text { EPR = Structural } \\
\text { changes on PE } \\
\text { uPVC, CA and } \\
\text { PET, partial } \\
\text { disruption of } \\
\text { Nylon and loss of } \\
\text { PES; } \\
\text { SPO (only on } \\
\text { PA6) = None }\end{array}$ & $\begin{array}{l}\text { CA not } \\
\text { identifiable }\end{array}$ & $\begin{array}{l}\text { Budimir } \\
\text { et al. } \\
\text { (2018) } \\
\text { Catarino } \\
\text { et al. } \\
\text { (2017) } \\
\text { Cole et } \\
\text { al., } 2014 \\
\text { Dehaut et } \\
\text { al. (2016) }\end{array}$ \\
\hline $\mathrm{KOH}$ & $\begin{array}{l}\text { Pristine pellets/fragments and from } \\
\text { consumer products (LDPE, PP, PET, } \\
\text { EVAVA19\%, PE-LLD recycled, SAN, } \\
\text { PA66, GPPS, PC, PA6, ABS, HDPE, CA, } \\
\text { PA-12, PC, PMMA, PS, PSXL, PTFE, } \\
\text { PUR, UPVC, ePS); }\end{array}$ & $\begin{array}{l}\text { EPR, SPO (G. gadus, } \\
P . \text { virens, mussels, } C \text {. } \\
\text { gariepinus, } S . \\
\text { sprattus fish); } \\
\text { FO (mussels, crabs, } \\
\text { black seabream; } C \text {. } \\
\text { farreri, } M \text {. } \\
\text { galloprovincialis } \\
\text { bivalves) }\end{array}$ & $5-48 \mathrm{~h}$ & Good & $\begin{array}{l}\text { EPR, } \\
\text { SPO=Structural } \\
\text { changes on CA, } \\
\text { PET and PVC }\end{array}$ & $\begin{array}{l}\text { Good but } \\
\text { slightly } \\
\text { altered } \\
\text { molecular } \\
\text { signals }\end{array}$ & $\begin{array}{l}\text { Dehaut et } \\
\text { al. (2016) } \\
\text { Enders et } \\
\text { al. (2017) } \\
\text { Ding et al. } \\
\text { (2018) } \\
\text { Karami et } \\
\text { al., } 2017 \\
\text { Kühn et } \\
\text { al. }(2017)\end{array}$ \\
\hline Protease K & $\begin{array}{l}\text { Pristine spheres (ePS, PP, PE); line (nylon); } \\
\text { fibre (PES); fragments (PE, PA, PET, ePS, } \\
\text { LDPE); granules (uPVC) }\end{array}$ & $\begin{array}{l}\text { EPR, FO (plankton; } \\
S . \text { trutta fish; } M \text {. } \\
\text { edulis mussels) }\end{array}$ & $24-48 \mathrm{~h}$ & $\begin{array}{l}\text { Presence } \\
\text { of } \\
\text { undigested } \\
\text { material }\end{array}$ & $\begin{array}{l}\text { None (except loss } \\
\text { of weight for } \\
\text { lighter polymers) }\end{array}$ & Good & $\begin{array}{l}\text { Cole et } \\
\text { al., 2014; } \\
\text { Karlsson } \\
\text { et al. } \\
(2017)\end{array}$ \\
\hline Corolase 7089 & $\begin{array}{l}\text { Industrially made fragments and flakes } \\
\text { (PET, HDPE, PVC), particles cut from } \\
\text { thread (nylon) }\end{array}$ & $\begin{array}{l}\text { SPO }(M . \text { edulis } \\
\text { mussels) } \\
\text { FO (M. edulis } \\
\text { mussels) }\end{array}$ & $1 \mathrm{~h}$ & Good & None & Good & $\begin{array}{l}\text { Catarino } \\
\text { et al. } \\
(2017)\end{array}$ \\
\hline Trypsin & $\begin{array}{l}\text { Fragments from consumer products (PET, } \\
\text { HDPE, PVC, PP, PS, PA) }\end{array}$ & $\begin{array}{l}\mathrm{EPR}, \mathrm{FO}(M . \text { edulis } \\
\text { mussels) }\end{array}$ & $30 \mathrm{~min}$ & Good & None & Good & $\begin{array}{l}\text { Courtene- } \\
\text { Jones et } \\
\text { al. } \\
(2017 b)\end{array}$ \\
\hline
\end{tabular}


Table 1 (Continued)

\begin{tabular}{|c|c|c|c|c|c|c|c|}
\hline Method & Test particles ${ }^{\mathrm{a}}$ & Test $^{\mathrm{b}} \&$ species & Duration & Efficacy & Physical changes & FTIR/Raman & Reference \\
\hline SDS + enzymes & Pristine beads (PE, PP) & $\begin{array}{l}\text { EPR and FO } \\
\text { (Plankton) }\end{array}$ & $10 \mathrm{~d}$ & Good & None & Good & $\begin{array}{l}\text { Löder et } \\
\text { al. (2017) }\end{array}$ \\
\hline
\end{tabular}

a $\mathrm{PS}=$ polystyrene; ePS = expanded polystyrene; $\mathrm{PES}=$ polyester; $\mathrm{PE}=$ polyethylene; $\mathrm{HDPE}=$ high density polyethylene; $\mathrm{LDPE}=$ low density polyethylene; $\mathrm{PA}=$ polyamide; $\mathrm{PET}=$ polyethylene terephthalate $\mathrm{PP}=$ polypropylene $\mathrm{CA}=$ cellulose acetate $\mathrm{PVC}=$ polyvinyl chloride; UPVC $=$ unplasticised polyvinyl chloride; $\mathrm{PC}=$ polycarbonate; PMMA = polymethylmethacrylate; $\mathrm{PTFE}=$ polytetrafluoroethylene; $\mathrm{PUR}=$ polyurethane; EVA = ethylene-vinyl acetate; $\mathrm{SAN}=$ styrene-acrylonitrile; $\mathrm{GPPS}=$ general purpose polystyrene; $\mathrm{ABS}=$ acrylonitrile butadiene styrene.

${ }^{\mathbf{b}} \mathrm{EPR}=$ direct exposure of MP to the chemicals used for the digestion; SPO=test of the digestion method on organisms tissue spiked with MP; FO=extraction of MP from field collected organisms).

et al., 2017; Cole et al., 2014; Dehaut et al., 2016; Ding et al., 2018; Enders et al., 2017; Karami et al., 2017; Kühn et al., 2017). Tissues from different species (birds, fish, bivalves) have been successfully digested with the use of $10 \%$ or $1 \mathrm{M}$ potassium hydroxide $(\mathrm{KOH})$ in a relatively short time (5-48 h), without any noticeable physical-chemical alterations in most polymer types. Cole et al., (2014) introduced enzymatic digestion with a serine protease (Proteinase K) as a biological method for hydrolysing proteins and breaking down tissues. Enzymatic digestion methods (e.g. with Proteinase K, Corolase 7089, Trypsin), which are widely used in forensic studies, appear to cause no damage to polymers. However, enzymatic-based approaches require long digestion times and multiple procedural steps (Löder et al., 2017), and may also result in incomplete tissue digestion (Karlsson et al., 2017).

\subsection{Efficiency of contamination prevention procedures}

No MP particles were found on the air filters or procedurals blanks. Only natural microfibres of cotton/cellulose (mostly white and blue with a distinctive morphology) were identified by visual inspection and were further confirmed by FTIR spectroscopy.

\subsection{Microplastic occurrence in C. aestuarii}

A total of $201 \mathrm{MP}$ particles were identified in the 180 crabs collected from lagoons in the northern Adriatic Sea, with an average $( \pm \mathrm{SE})$ of $1.1 \pm 0.7$ particles per individual. However, only 10 individual crabs contained MP, and there was a high variability in the number of particles among individuals: 8 of the 10 individuals contained only 1 synthetic particle, while 2 individuals had 117 and 76 plastic particles respectively (Fig. 1a and Table S2, Supplementary Information). All MP were identified as monofilament microfibres with the a)

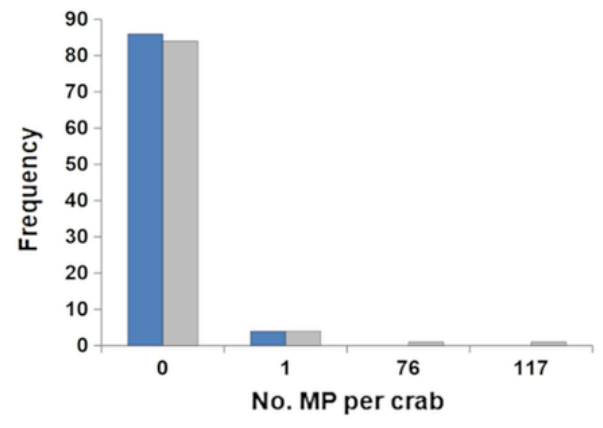

c)

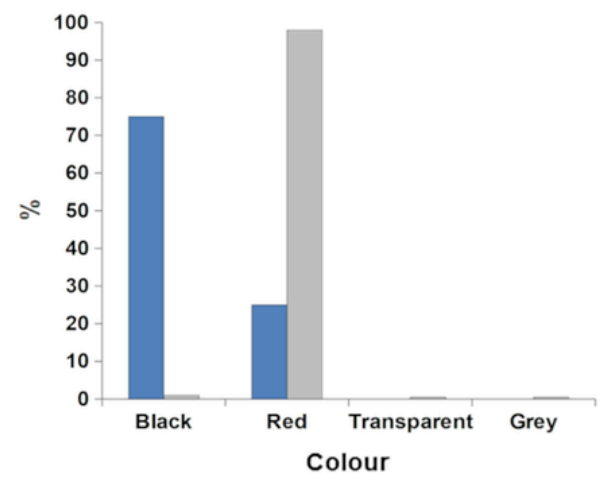

b)

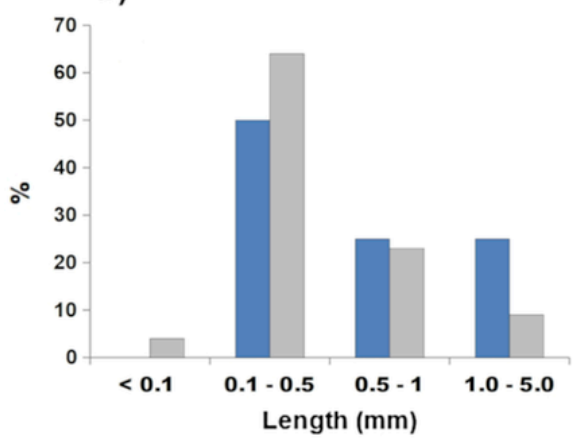

d)

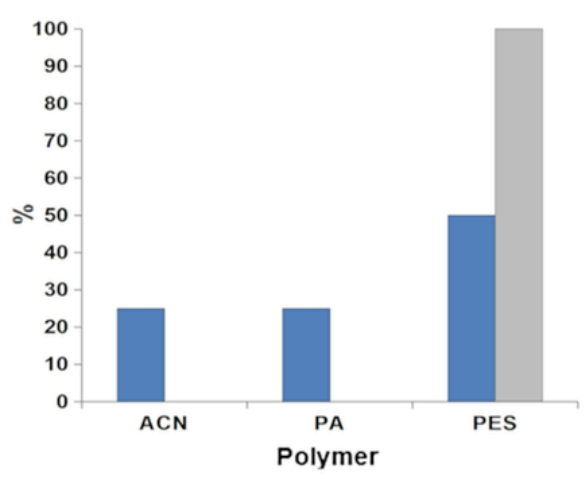

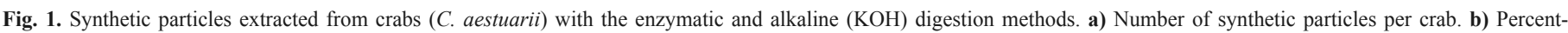

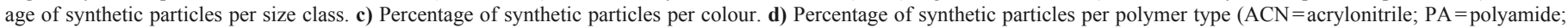
$\mathrm{PES}=$ polyester). (For interpretation of the references to colour in this figure legend, the reader is referred to the Web version of this article.) 
exception of one multifilament microfibre. The microfibres ranged in length from 0.03 to $3 \mathrm{~mm}$, with an average length $( \pm \mathrm{SE})$ of $0.5 \pm 0.03 \mathrm{~mm}$ (Fig. 1b). Most microfibres were red or black in colour (Fig. 1c), and the most frequent polymer was PES (99\%) (Fig. 1d). The characteristics (length, colour, polymer type) of each individual microfibre, the generated FTIR spectra, and the reference spectra used for identification are reported in Figs. S1, S2, S3 and in Table S2 of the Supplementary Information.

\subsection{Comparison of digestion methods}

\subsubsection{Occurrence of microplastic in field organisms}

The number of MP particles extracted from crabs did not differ significantly between the enzymatic and alkaline methods (Mann-Withney-Wilkoxon test $\mathrm{p}$-value $=0.5)$. Only 4 out of the $90 \mathrm{crabs}(4 \%)$ digested with the enzymatic method contained MP (Fig. 1a) with an average $( \pm$ SE) of $0.04( \pm 0.02)$ per individual (Table S1, Supplementary Information). All MP particles were microfibres, with most being black in colour (Fig. 1c). Only 6 out of the 90 crabs (7\%) digested with $\mathrm{KOH}$ contained MP (Fig. 1a), with an average $( \pm$ SE) of $2.19( \pm 1.5)$ per organism (Table S2, Supplementary Information). All MP particles were microfibres, with most being red, followed by black, transparent and grey (Fig. 1c).

The microfibres extracted from crabs digested with the enzymatic method ranged from 0.19 to $2.55 \mathrm{~mm}$ (mean $\pm \mathrm{SE}=0.94 \pm 0.5 \mathrm{~mm}$ ) in length, with $50 \%(\mathrm{n}=2)$ being $0.1-0.5 \mathrm{~mm}$ long and the others being $0.5-1 \mathrm{~mm}(25 \%, \mathrm{n}=1)$ and $1-5 \mathrm{~mm}(25 \%, \mathrm{n}=1)$ (Fig. 1b). The microfibres extracted with $\mathrm{KOH}$ ranged had a mean length $( \pm \mathrm{SE})$ of $0.51 \pm 0.03 \mathrm{~mm}$, but exhibited more variation in their length, with $64 \%$ $(\mathrm{n}=126)$ being $0.1-0.5 \mathrm{~mm}, 23 \%(\mathrm{n}=45)$ being $0.5-1 \mathrm{~mm}$, and small percentage being $1-5 \mathrm{~mm}(9 \%, \mathrm{n}=18)$ ) and $<0.1 \mathrm{~mm}(4 \%, \mathrm{n}=8)$ (Fig. 1b). No particles/microfibres from either digestion method presented signs of discoloration or morphological degradation. Fig. 2 provides

a)

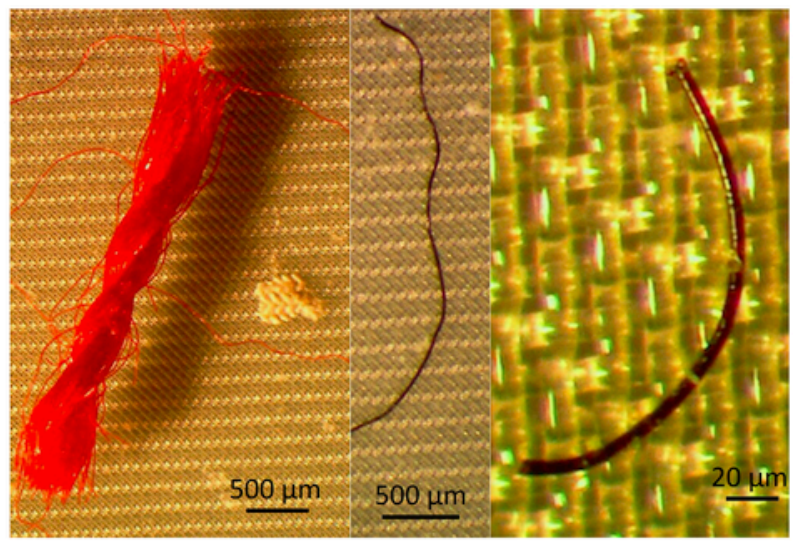

b)

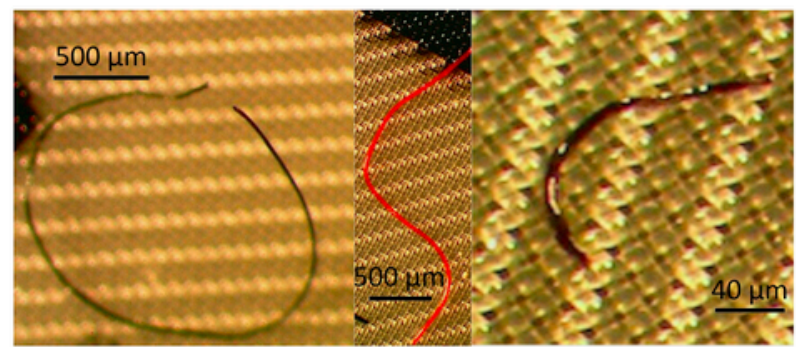

Fig. 2. Photographic examples of fibres extracted from the gastrointestinal tracts of crabs (C. aestuarii) digested with a) the alkaline $(\mathrm{KOH})$ method (polyester), and b) the enzymatic method (from left to right: polyamide, polyester, acrylonitrile). photographic examples of the microfibres extracted with the enzymatic (Fig. 2b) and alkaline (Fig. 2a) digestion methods. FTIR analysis of the microfibres extracted from crabs digested with enzymes indicated that $\sim 50 \%(\mathrm{n}=2)$ were PES, $25 \%(\mathrm{n}=1)$ were polyamide $(\mathrm{Ny}$ lon) and $25 \%(n=1)$ were acrylonitrile (Orlon), while 100\% $(n=197)$ of the microfibres isolated from crabs treated with $\mathrm{KOH}$ were PES (Fig. 1d).

\subsubsection{Comparison of contamination risks}

The quantity of non-synthetic anthropogenic microfibres in the procedural blanks (Fig. 3a) and air filters (Fig. 3b) did not differ significantly between the enzymatic and alkaline digestion methods ( $t$-test $\mathrm{p}$-values $=0.4$ and 0.8 , respectively). The average $( \pm \mathrm{SE})$ number of non-synthetic anthropogenic microfibres in the procedural blanks and air filters was $3.5 \pm 0.5$ and $1.5 \pm 0.3$ for the enzymatic method and $3.1 \pm 0.4$ and $1.6 \pm 0.3$ for the alkaline method.

\subsubsection{Effects of the digestion procedures on synthetic microfibres}

Most of the laboratory-prepared microfibres that were treated with the enzymatic method and the alkaline method did not exhibit any clear structural changes (e.g. colour or shape) or damage (Fig. 4a and b). According to the scale of impact developed by Enders et al. (2017), all polymers treated with the enzymatic digestion method

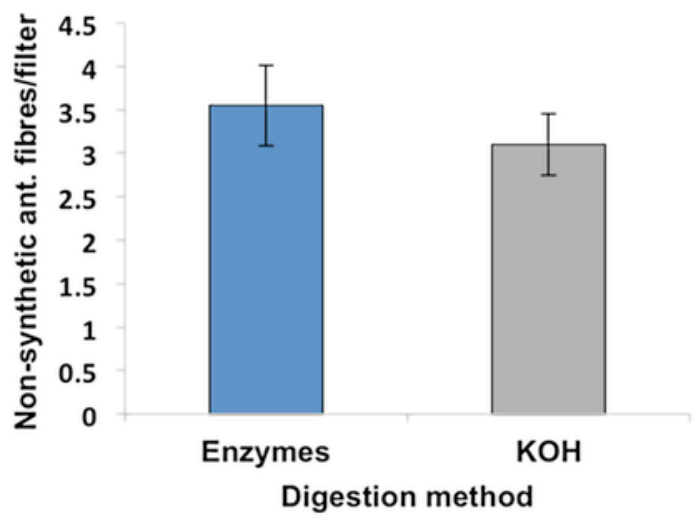

a)

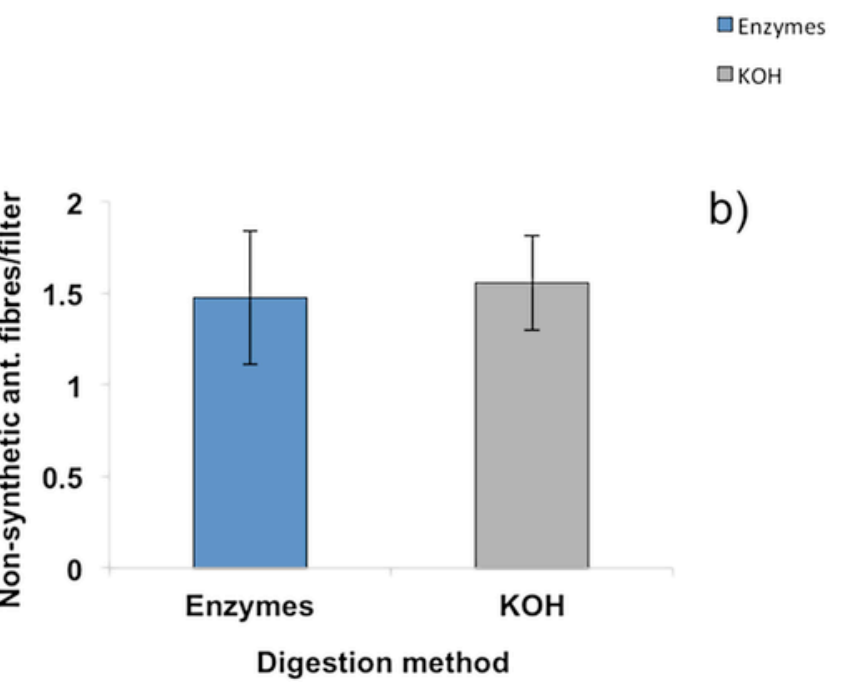

Fig. 3. Average $( \pm \mathrm{SE})$ number of non-synthetic anthropogenic particles in a) procedural blanks $(n=20)$ and $\mathbf{b})$ air filters $(n=40 ; n=36)$ associated to either enzymatic or alkaline $(\mathrm{KOH})$ methods. 


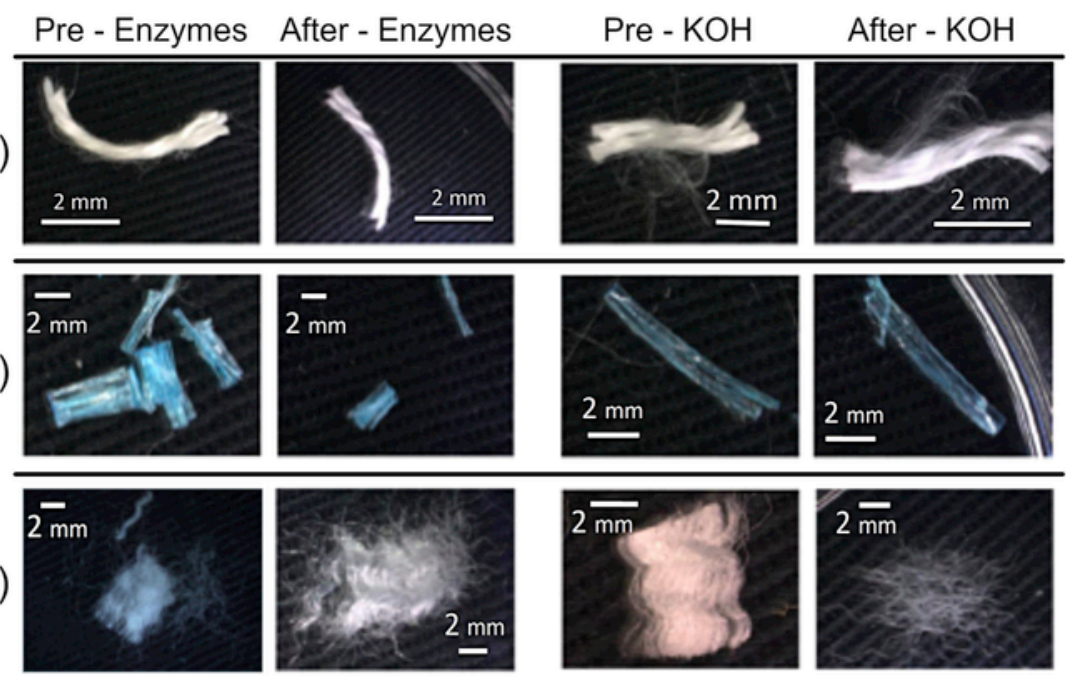

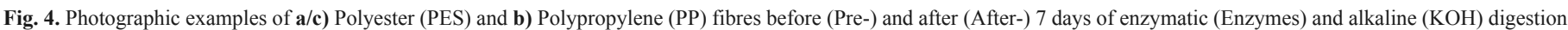
treatment.

were classified as being 'L0 degraded' (i.e. no changes) after a period of 7 days. No alteration (L0) was observed for any type of microfibre exposed to the $\mathrm{KOH}$ treatment for up to 4 days. However, one type of PES microfibres presented signs of discoloration and moderate structural changes (classified as L3) after 7 days of exposure to the $\mathrm{KOH}$ solution (Fig. 4c). None of the microfibres showed any significant change in their FTIR spectra compared to the untreated control materials, irrespective of the digestion method, duration or polymer type (Figs. S4-S5, Supplementary Information).

\section{Discussion}

This study represents one the first empirical field assessments of MP occurrence in the gastrointestinal tract of $C$. aestuarii. Extensive field studies on large sample volumes of organisms and environmental samples are still scarce and, in many cases, do not consider microfibres in their quantifications. This is mainly due operational difficulties in applying effective contamination prevention practices on these types of extremely mobile and ubiquitous MP particles. The current study demonstrates that effective contamination prevention procedures can be implemented successfully and allow the reliable extraction and quantification of synthetic microfibres in wild organisms. As a result, future studies should consider implementing equivalent measures so that microfibres, which appear to be a significant proportion of the total environmental MP load, can be quantified.

Interestingly, this study showed that most crabs $(96 \%$ of 180 organisms) did not contain any MP in their gastrointestinal tract, and where organisms did contain MP they were exclusively microfibres. The average MP content $(1.1 \pm 0.7 \mathrm{SE}$ microfibres per crab) was within the range of values reported for other coastal invertebrates such as the coastal shrimp C. crangon and fish (Devriese et al., 2015; Lusher et al., 2013). However, studies on MP in crabs are scarce, which makes it difficult to make robust comparisons. Furthermore, the MP content was extremely variable among individuals, which is in line with observations made in previous studies on other marine species (Lusher et al., 2013; Nelms et al., 2018). While most crabs did not contain any MP, two individuals had $>50$ microfibres in their gastrointestinal tracts. Currently the drivers behind such large variability are unknown, but it is suggested that these variable levels of MP occurrence could reflect differences in uptake and egestion rates among individual crabs (Watts et al., 2015), small-scale patchiness in the distribution and bioavailability of MP particles in the environment (Lourenço et al., 2017) and/or in prey items (Batel et al., 2016; Mattsson et al., 2017; Tosetto et al., 2017). Bour et al. (2018) described a variable occurrence of MP within many species including bivalves which are, together with polychaetes the main food-source of the predator $C$. aestuarii. However, data regarding small-scale variability at any environmental compartments or trophic levels are still scarce and more studies are needed in this direction.

The observed MP variability may also originate as a consequence of moulting events. During moulting, particularly observed during Summer and Autumn (Chen et al., 2004), crabs experience periods of starvation (Sánchez-Paz et al., 2006), therefore an early moulting event before the sampling could have reduced the uptake of MP for the majority of the examined crabs. Another possible explanation could be that the high quantity of microfibres found in two crabs resulted from the fragmentation of multifilament plastic items during the ingestion and passage through the gastrointestinal tract. In fact, another crab, from the same area, showed a multifilament microfibre with similar properties (length, colour and polymer) of the individual microfibres from the two highly contaminated crabs.

Microfibres constituted $100 \%$ of the synthetic particles found in the analysed organisms, confirming that microfibres are the most prevalent synthetic particles in benthic invertebrates (Claessens et al., 2011; Lourenço et al., 2017; Taylor et al., 2016). This could reflect a greater occurrence and bioavailability of microfibres compared to other types of particles (e.g. fragments, films, pellets) in the system. Indeed, microfibres originate from a variety of sources and make up $85 \%$ of human-made debris on shorelines around the world (Browne et al., 2011). However, the few available environmental data from the north Adriatic lagoon region where the crabs were sampled in the current study (Vianello et al., 2013) indicate that only a small fraction of MP particles in the sediments are microfibres. Despite appearing to be less abundant than fragments in this ecosystem, the prevalence of microfibres in the gastrointestinal tract of crabs may be due to their physical properties relative to other types of MP. The high aspect ratio of microfibres and their propensity to become entangled with each other and with biological features may lead to longer retention times caused by a slower transit through the digestive system. In contrast, fragments and spheres have been shown to pass quickly through the 
gastrointestinal tract and readily excreted (Watts et al., 2015). Further work should explore uptake and egestion rates of MP in relation to both their physical-chemical properties and environmental distribution, to clarify what factors control the distribution of microfibres in the biota (Lourenço et al., 2017).

The length of microfibres found in our analyses were within the same size range of those found by Devriese et al. (2015) in the coastal shrimp C. crangon but smaller of those reported in various mediterrean and atlantic fish species (e.g.Avio et al., 2015a,b; Lusher et al., 2013; Nelms et al., 2018). This may depend on the different feeding physiology (e.g. particle selectivity), mobility, marine compartments of the considered species and/or on the different microfibers sources (Devriese et al., 2015). Among all synthetic particles extracted, the dominating polymer type was PES which, together with acrylic and polyamide, is denser than sea water (Courtene-Jones et al., 2017a), thus probably sinking faster into the sediments (Linders et al., 2018).

A slightly greater variability in polymer composition was observed in crabs processed with the enzymatic method than in those digested with $\mathrm{KOH}$, where $100 \%$ of particles/fibres were PES. Given the low number of individuals with MP and the very large variability in the number of particles among those few individuals (from 1 to 117 particles per individual), it is difficult to determine if this occurred only by chance or if the $\mathrm{KOH}$ digestion process resulted in destruction of certain polymer classes. Moreover, the subsequent laboratory tests with $\mathrm{KOH}$ on the prepared microfibres did not result in any noticeable changes to their physical-chemical structure, which is in line with previous results reported by Kühn et al. (2017). Thus, we can probably exclude the occurrence of polymer disruption by $\mathrm{KOH}$ in our study.

When considering the outcomes of the methodological review, the laboratory tests confirmed that enzymatic digestion is a gentle digestion method, also applicable when longer ( $>4$ days) digestions are required (Cole et al., 2014; Courtene-Jones et al., 2017a,b). However, the enzymatic treatment may not result in a complete digestion of biological tissues, making the subsequent visual inspection more difficult and time consuming (Karlsson et al., 2017). The $\mathrm{KOH}$ digestion method did not cause any observable physical-chemical changes to any of the tested polymer microfibres when treated for up to 4 days, consistent with reports from other studies (Dehaut et al., 2016; Enders et al., 2017; Karami et al., 2017; Kühn et al., 2017). After a KOH digestion period of 7 days some of the PES microfibres exhibited slight morphological changes suggesting degradation is occurring, but none of the other microfibre types were affected. This impact of $\mathrm{KOH}$ has also been observed by Dehaut et al. (2016) on pristine PES granules particularly characterised as polyethylene terephthalate (PET). The effect of $\mathrm{KOH}$ is most unlikely to be a problem when studying MP occurrence in most smaller-sized invertebrates, where the time required for tissue digestion is short (e.g. in the current study $<3$ days). However, it suggests the need for caution when long digestion times are required, for example when large quantities of soft tissues are to be digested. Independently of exposure time (up to 7 days), neither digestion method affected the chemical structure of microfibres that prevented ready identification by FTIR.

The careful contamination prevention procedures adopted in our study successfully limited any external plastic contamination of the samples. However, a slightly higher amount of non-synthetic cotton and cellulose microfibres (from laboratory coats and cleaning tissue) were observed in the procedural blanks from the enzymatic digestion procedure. This most likely related to the longer processing time (5 days), a more difficult filtration of the digestate and the higher quantity of steps involved in the procedure. Importantly, this suggests that the enzymatic procedure has a higher potential risk for introducing airborne MP contamination to the samples, in addition to the increased potential for loss and underestimation of the number MP particles.

Overall, the $\mathrm{KOH}$ procedure was less time consuming, considerably cheaper, and had a lower contamination risk than the enzymatic digestion method. When using $\mathrm{KOH}$, the digestion of the whole gastrointestinal tract of 90 crabs required only 2 days, fewer procedural steps and a low cost per sample (due to cheaper reagents). In contrast, the enzymatic digestion required 5 days, more procedural steps and was more time consuming during the filtration step due to the very viscous consistency of the digestate. Even using enzymes from laundry detergents, which are already cheaper than purchasing the pure enzymes usually used for laboratory analyses, the cost per sample was 40 times higher than with the $\mathrm{KOH}$ procedure.

\section{Conclusion}

The current study empirically demonstrated a low and variable occurrence of MP particles in the gastrointestinal tract of the shore crab Carcinus aestuarii collected from north Adriatic coastal lagoons. While most individuals did not contain any MP, a small number contained extremely high numbers (up to 117) that were identified as synthetic polymer microfibres in all cases. To accurately understand the sources and impacts of MP on biota, it is essential to use extraction and analysis methods that allow quantification and characterisation of microfibres as well as other types of MP. This is important when studies that do report the presence of microfibres often find them to be the most prevalent type of MP debris in environmental samples (water, sediment and biota). Future research should focus on measuring ingestion/egestion rates of different types of MP particles by benthic marine invertebrates, to try and gain a clearer understanding of the highly variable occurrence observed in both the current and other studies. Although both digestion methods tested are applicable for the digestion of biological samples, the $\mathrm{KOH}$ method has a lower risk for contamination and is the most cost-effective and efficient, particularly when applied for large-scale monitoring purposes. However, an optimised enzymatic method could represent a better alternative for large invertebrates and fish, for which long ( $>4$ days) digestion times are required.

\section{Notes}

This work has been conducted under the framework of the JPI Oceans project 'PLASTOX' (Direct and indirect ecotoxicological impacts of microplastics on marine organisms grant agreement No 696324). The work has been funded by: the MIUR-Italian Ministry of Education, University and Research (protocollo No. 6962 31/03/2015) , the Research Council of Norway (grant agreement No. 257479) and the Swedish Formas (grant agreement No. 942-2015-1862). S. Piarulli was covered by a $\mathrm{PhD}$ grant from the University of Bologna. Additional funding was also provided by projects RFO and Adriacoast (L. Airoldi).

\section{Acknowledgments}

We thank Paolo Mancuso, $\mathrm{PhD}$, for his advice and support during the analyses and writing process and Gianluca Chiapponi for his kind support during the FTIR analysis. We also wish to thank the anonymous reviewers who significantly contributed to improving the original manuscript. 


\section{Appendix A. Supplementary data}

Supplementary data to this article can be found online at https:// doi.org/10.1016/j.envpol.2019.04.092.

\section{References}

Airoldi, L., Ponti, M., Abbiati, M., 2016. Conservation challenges in human dominated seascapes: the harbour and coast of Ravenna. Reg. Stud. Mar. Sci. 8, 308-318 https://doi.org/10.1016/j.rsma.2015.11.003.

Aljaibachi, R., Callaghan, A., 2018. Impact of Polystyrene Microplastics on Daphnia Magna Mortality and Reproduction in Relation to Food Availability. https://doi. org $/ 10.7717$ peerj. 4601

Andrady, A.L., 2011. Microplastics in the marine environment. Mar. Pollut. Bull. 62, 1596-1605 https://doi.org/10.1016/j.marpolbul.2011.05.030.

Avio, C.G., Gorbi, S., Milan, M., Benedetti, M., Fattorini, D., D'Errico, G., Pauletto, M., Bargelloni, L., Regoli, F., 2015a. Pollutants bioavailability and toxicological risk from microplastics to marine mussels. Environ. Pollut. 198, 211-222 https:// doi.org/10.1016/j.envpol.2014.12.021.

Avio, C.G., Gorbi, S., Regoli, F., 2015b. Experimental development of a new protocol for extraction and characterization of microplastics in fish tissues: first observations in commercial species from Adriatic Sea. Mar. Environ. Res. 111, 18-26 https://doi.org/10.1016/j.marenvres.2015.06.014.

Barnes, D.K. a., Galgani, F., Thompson, R.C., Barlaz, M., 2009. Accumulation and fragmentation of plastic debris in global environments. Philos. Trans. R. Soc. B Biol. Sci. 364, 1985-1998 https://doi.org/10.1098/rstb.2008.0205.

Batel, A., Borchert, F., Reinwald, H., Erdinger, L., Braunbeck, T., 2018. Microplastic accumulation patterns and transfer of benzo [a ] pyrene to adult zebra fish ( Danio rerio ) gills and zebra fish embryos *. Environ. Pollut. 235, 918-930 https://doi. org/10.1016/j.envpol.2018.01.028

Batel, A., Linti, F., Scherer, M., Erdinger, L., Braunbeck, T., 2016. Transfer of benzo[a]pyrene from microplastics to Artemia nauplii and further to zebrafish via a trophic food web experiment: CYP1A induction and visual tracking of persistent organic pollutants. Environ. Toxicol. Chem. 35, 1656-1666 https://doi.org/10. 1002/etc. 3361.

Besseling, E., Wegner, A., Foekema, E.M., Van Den Heuvel-Greve, M.J., Koelmans, A. a., 2013. Effects of microplastic on fitness and PCB bioaccumulation by the lugworm Arenicola marina. Environ. Sci. Technol. 47, 593-600 https://doi.org/10. 1021/es302763x.

Boucher, J., Friot, D., 2017. Primary microplastics in the oceans: global evaluation of sources. Int. Union Conserv. Nat. Nat. Resour. https://doi.org/dx.doi.org/10.2305/ IUCN.CH.2017.01.en.

Bour, A., Giacomo, C., Gorbi, S., Regoli, F., 2018. Presence of microplastics in benthic and epibenthic organisms: influence of habitat, feeding mode and trophic level *. Environ. Pollut. 243, 1217-1225 https://doi.org/10.1016/j.envpol.2018.09. 115 .

Browne, M. a., Dissanayake, A., Galloway, T.S., Lowe, D.M., Thompson, R.C., 2008 Ingested microscopic plastic translocates to the circulatory system of the mussel, Mytilus edulis. Environ. Sci. Technol. 42, 5026-5031 https://doi.org/10.1021/ es800249a.

Browne, M.A., Crump, P., Niven, S.J., Teuten, E., Tonkin, A., Galloway, T., Thompson, R., 2011. Accumulation of microplastic on shorelines woldwide: sources and sinks. Environ. Sci. Technol. 45, 9175-9179 https://doi.org/10.1021/es201811s.

Budimir, S., Setälä, O., Lehtiniemi, M., 2018. Effective and easy to use extraction method shows low numbers of microplastics in offshore planktivorous fish from the northern Baltic Sea. Mar. Pollut. Bull. 127, 586-592 https://doi.org/10.1016/j. marpolbul.2017.12.054

Capolupo, M., Franzellitti, S., Valbonesi, P., Sanz, C., Fabbri, E., 2018. Uptake and transcriptional effects of polystyrene microplastics in larval stages of the Mediterranean mussel Mytilus galloprovincialis *. Environ. Pollut. 241, 1038-1047 https: //doi.org/10.1016/j.envpol.2018.06.035

Catarino, A.I., Thompson, R., Sanderson, W., Henry, T.B., 2017. Development and optimization of a standard method for extraction of microplastics in mussels by enzyme digestion of soft tissues. Environ. Toxicol. Chem. 36, 947-951 https://doi. org/10.1002/etc. 3608 .

Chen, R. Bin, Watanabe, S., Yokota, M., 2004. Feeding habits of an exotic species, the Mediterranean green crab Carcinus aestuarii. In: Tokyo Bay. Fish. Scie, vol. 70 , pp. 430-435.

Claessens, M., Meester, S., De Landuyt, L., Van Clerck, K. De, Janssen, C.R., 2011 Occurrence and distribution of microplastics in marine sediments along the Belgian coast. Mar. Pollut. Bull. 62, 2199-2204 https://doi.org/10.1016/j.marpolbul. 2011.06.030.

Claessens, M., Van Cauwenberghe, L., Vandegehuchte, M.B., Janssen, C.R., 2013. New techniques for the detection of microplastics in sediments and field col- lected organisms. Mar. Pollut. Bull. 70, 227-233 https://doi.org/10.1016/j. marpolbul.2013.03.009.

Codina-García, M., Militão, T., Moreno, J., González-Solís, J., 2013. Plastic debris in Mediterranean seabirds. Mar. Pollut. Bull. 77, 220-226 https://doi.org/10.1016/j. marpolbul.2013.10.002.

Cole, M., Lindeque, P., Fileman, E., Halsband, C., Goodhead, R., Moger, J., Galloway, T.S., 2013. Microplastic ingestion by zooplankton. Environ. Sci. Technol. 47, 6646-6655 https://doi.org/10.1021/es400663f.

Cole, M., Lindeque, P., Halsband, C., Galloway, T.S., 2011. Microplastics as contaminants in the marine environment: a review. Mar. Pollut. Bull. 62, 2588-2597 https: //doi.org/10.1016/j.marpolbul.2011.09.025.

Cole, M., Webb, H., Lindeque, P.K., Fileman, E.S., Halsband, C., Galloway, T.S., 2014. Isolation of microplastics in biota-rich seawater samples and marine organisms. Sci. Rep. 4, 4528 https://doi.org/10.1038/srep04528.

Carbery, M., Connor, W.O., Thavamani, P., 2018. Trophic transfer of microplastics and mixed contaminants in the marine food web and implications for human health. Environ. Int. 115, 400-409 https://doi.org/10.1016/j.envint.2018.03.007.

Courtene-Jones, W., Quinn, B., Gary, S.F., Mogg, A.O.M., Narayanaswamy, B.E., 2017a. Microplastic pollution identified in deep-sea water and ingested by benthic invertebrates in the Rockall Trough, North Atlantic Ocean. Environ. Pollut. 231, 271-280 https://doi.org/10.1016/j.envpol.2017.08.026.

Courtene-Jones, W., Quinn, B., Murphy, F., Gary, S.F., Narayanaswamy, B.E., 2017 b. Optimisation of enzymatic digestion and validation of specimen preservation methods for the analysis of ingested microplastics. Anal. Methods 9, 1437-1445 https://doi.org/10.1039/C6AY02343F.

De Witte, B., Devriese, L., Bekaert, K., Hoffman, S., Vandermeersch, G., Cooreman, K., Robbens, J., 2014. Quality assessment of the blue mussel (Mytilus edulis): comparison between commercial and wild types. Mar. Pollut. Bull. 85, 146-155 https://doi.org/10.1016/j.marpolbul.2014.06.006.

Dehaut, A., Cassone, A.L., Frère, L., Hermabessiere, L., Himber, C., Rinnert, E., Rivière, G., Lambert, C., Soudant, P., Huvet, A., Duflos, G., Paul-Pont, I., 2016. Microplastics in seafood: benchmark protocol for their extraction and characterization. Environ. Pollut. 215, 223-233 https://doi.org/10.1016/j.envpol.2016.05.018

Devriese, L.I., van der Meulen, M.D., Maes, T., Bekaert, K., Paul-Pont, I., Frère, L., Robbens, J., Vethaak, a. D., 2015. Microplastic contamination in brown shrimp (Crangon crangon, linnaeus 1758) from coastal waters of the southern north Sea and channel area. Mar. Pollut. Bull. 98, 179-187 https://doi.org/10.1016/j. marpolbul.2015.06.051.

Ding, J.F., LI, J.X., Sun, C.J., HE, C.F., Jiang, F.H., Gao, F.L., Zheng, L., 2018. Separation and identification of microplastics in digestive system of bivalves. Chin. J. Anal. Chem. 46, 690-697 https://doi.org/10.1016/S1872-2040(18)61086-2.

Enders, K., Lenz, R., Beer, S., Stedmon, C. a., 2017. Extraction of microplastic from biota: recommended acidic digestion destroys common plastic polymers. ICES J. Mar. Sci. 74, 326-331 https://doi.org/10.1093/icesjms/fsw173.

Iso, M., 2018. My ISO Job.

Karami, A., Golieskardi, A., Choo, C.K., Romano, N., Ho, Y. Bin, Salamatinia, B., 2017. A high-performance protocol for extraction of microplastics in fish. Sci. Total Environ. 578, 485-494 https://doi.org/10.1016/j.scitotenv.2016.10.213.

Karlsson, T.M., Vethaak, a. D., Almroth, B.C., Ariese, F., van Velzen, M., Hassellöv, M., Leslie, H. a., 2017. Screening for microplastics in sediment, water, marine invertebrates and fish: method development and microplastic accumulation. Mar. Pollut. Bull. 122, 403-408 https://doi.org/10.1016/j.marpolbul.2017.06.081.

Kühn, S., van Werven, B., van Oyen, A., Meijboom, A., Bravo Rebolledo, E.L., van Franeker, J. a., 2017. The use of potassium hydroxide $(\mathrm{KOH})$ solution as a suitable approach to isolate plastics ingested by marine organisms. Mar. Pollut. Bull. 115, 86-90 https://doi.org/10.1016/j.marpolbul.2016.11.034.

Linders, T., Infantes, E., Joyce, A., Karlsson, T., Ploug, H., Hassellöv, M., Sköld, M., Zetsche, E.-M., 2018. Particle sources and transport in stratified Nordic coastal seas in the Anthropocene. Elem. Sci. Anthropol. 6, 29 https://doi.org/10.1525/ elementa.149.

Löder, M.G.J., Imhof, H.K., Ladehoff, M., Löschel, L. a., Lorenz, C., Mintenig, S., Piehl, S., Primpke, S., Schrank, I., Laforsch, C., Gerdts, G., 2017. Enzymatic purification of microplastics in environmental samples. Environ. Sci. Technol. 51, 14283-14292 https://doi.org/10.1021/acs.est.7b03055.

Lourenço, P.M., Serra-Gonçalves, C., Ferreira, J.L., Catry, T., Granadeiro, J.P., 2017. Plastic and other microfibers in sediments, macroinvertebrates and shorebirds from three intertidal wetlands of southern Europe and west Africa. Environ. Pollut. 231, 123-133 https://doi.org/10.1016/j.envpol.2017.07.103.

Lusher, a. L., McHugh, M., Thompson, R.C., 2013. Occurrence of microplastics in the gastrointestinal tract of pelagic and demersal fish from the English Channel. Mar. Pollut. Bull. 67, 94-99 https://doi.org/10.1016/j.marpolbul.2012.11.028.

Lusher, A.L., Hernandez-Milian, G., O'Brien, J., Berrow, S., O'Connor, I., Officer, R., 2015. Microplastic and macroplastic ingestion by a deep diving, oceanic cetacean: the True's beaked whale Mesoplodon mirus. Environ. Pollut. 199, 185-191 https:// doi.org/10.1016/j.envpol.2015.01.023.

Mato, Y., Isobe, T., Takada, H., Kanehiro, H., Ohtake, C., Kaminuma, T., 2001. Plastic resin pellets as a transport medium for toxic chemicals in the marine en- 
vironment. Environ. Sci. Technol. 35, 318-324 https://doi.org/10.1021/es0010498.

Mattsson, K., Johnson, E.V., Malmendal, A., Linse, S., 2017. Brain damage and behavioural disorders in fish induced by plastic nanoparticles delivered through the food chain. Sci. Rep. 1-7 https://doi.org/10.1038/s41598-017-10813-0.

Mistri, M., 2004. Prey preference of Carcinus aestuarii: possible implications with the control of an invasive mytilid and Manila clam culture in a northern Adriatic lagoon. Aquaculture 230, 261-272 https://doi.org/10.1016/S0044-8486(03)00441-1

Mistri, M., Fano, E.A., Rossi, R., 2001. Macrofaunal secondary production in a lagoon of the po river delta: an evaluation of estimation methods. Ital. J. Zool. 68, 147-151 https://doi.org/10.1080/11250000109356399.

Naidoo, T., Goordiyal, K., Glassom, D., 2017. Are nitric acid (HNO3) digestions efficient in isolating microplastics from juvenile fish? Water. Air. Soil Pollut. 228, https://doi.org/10.1007/s11270-017-3654-4.

Napper, I.E., Thompson, R.C., 2016. Release of synthetic microplastic plastic fibres from domestic washing machines: effects of fabric type and washing conditions. Mar. Pollut. Bull. 112, 39-45 https://doi.org/10.1016/j.marpolbul.2016.09.025.

Nelms, S.E., Galloway, T.S., Godley, B.J., Jarvis, D.S., Lindeque, P.K., 2018. Investigating microplastic trophic transfer in marine top predators. Environ. Pollut. 1-9 https://doi.org/10.1016/j.envpol.2018.02.016

Özbek, M., Koçak, C., Acarli, D., 2012. Reproductive biology of the mediterranean green crab Carcinus aestuarii Nardo, 1847 (Crustacea, Brachyura, portunidae) in homa lagoon, Aegean sea, Turkey. Oceanol. Hydrobiol. Stud. 41, 77-80 https:// doi.org/10.2478/s13545-012-0041-z.

Panel, E., Chain, F., 2016. Presence of microplastics and nanoplastics in food, with particular focus on seafood. EFSA J 14, https://doi.org/10.2903/j.efsa.2016.4501.

Rochman, C.M., Hoh, E., Kurobe, T., Teh, S.J., 2013. Ingested plastic transfers hazardous chemicals to fish and induces hepatic stress. Sci. Rep. 3, $3263 \mathrm{https}: / /$ doi. org/10.1038/srep03263.

Sánchez-Paz, A., García-Carreño, F., Muhlia-Almazán, A., Peregrino-Uriarte, A.B. Hernández-López, J., Yepiz-Plascencia, G., 2006. Usage of energy reserves in crustaceans during starvation: status and future directions. Insect Biochem. Mol. Biol. 36, 241-249 https://doi.org/10.1016/j.ibmb.2006.01.002.

Setälä, O., Fleming-Lehtinen, V., Lehtiniemi, M., 2014. Ingestion and transfer of microplastics in the planktonic food web. Environ. Pollut. 185, 77-83 https://doi.org 10.1016/j.envpol.2013.10.013.

Sleight, V.A., Bakir, A., Thompson, R.C., Henry, T.B., 2017. Assessment of microplastic-sorbed contaminant bioavailability through analysis of biomarker gene expression in larval zebra fish. Mar. Pollut. Bull. 116, 291-297 https://doi.org/10. 1016/j.marpolbul.2016.12.055.

Straub, S., Hirsch, P.E., Burkhardt-holm, P., 2017. Biodegradable and Petroleum-Based Microplastics Do Not Differ in Their Ingestion and Excretion but in Their Biological Effects in a Freshwater Invertebrate Gammarus Fossarum. https:// doi.org/10.3390/ijerph14070774.

Taylor, M.L., Gwinnett, C., Robinson, L.F., Woodall, L.C., 2016. Plastic microfibre ingestion by deep-sea organisms. Sci. Rep. 6, 33997 https://doi.org/10.1038/ srep33997.

Teuten, E.L., Saquing, J.M., Knappe, D.R.U., Barlaz, M. a., Jonsson, S., Bjorn, a., Rowland, S.J., Thompson, R.C., Galloway, T.S., Yamashita, R., Ochi, D., Watanuki, Y., Moore, C., Viet, P.H., Tana, T.S., Prudente, M., Boonyatu- manond, R., Zakaria, M.P., Akkhavong, K., Ogata, Y., Hirai, H., Iwasa, S. Mizukawa, K., Hagino, Y., Imamura, a., Saha, M., Takada, H., 2009. Transport and release of chemicals from plastics to the environment and to wildlife. Philos. Trans. R. Soc. B Biol. Sci. 364, 2027-2045 https://doi.org/10.1098/rstb.2008.0284

Tosetto, L., Williamson, J.E., Brown, C., 2017. Trophic transfer of microplastics doe not affect fish personality. Anim. Behav. 123, 159-167 https://doi.org/10.1016/j. anbehav.2016.10.035.

Tourinho, P.S., Ivar do Sul, J. a., Fillmann, G., 2010. Is marine debris ingestion still a problem for the coastal marine biota of southern Brazil?. Mar. Pollut. Bull. 60, 396-401 https://doi.org/10.1016/j.marpolbul.2009.10.013.

Unep, 2009. Marine Litter: A Global Challenge. United Nations Environmental Programme (UNEP).

Van Cauwenberghe, L., Claessens, M., Vandegehuchte, M.B., Janssen, C.R., 2015. Microplastics are taken up by mussels (Mytilus edulis) and lugworms (Arenicola marina) living in natural habitats. Environ. Pollut. 199, 10-17 https://doi.org/10. 1016/j.envpol.2015.01.008.

Van Cauwenberghe, L., Janssen, C.R., 2014. Microplastics in bivalves cultured for human consumption. Environ. Pollut. 193, 65-70 https://doi.org/10.1016/j.envpol. 2014.06.010.

Vermeiren, P., Muñoz, C.C., Ikejima, K., 2016. Sources and sinks of plastic debris in estuaries: a conceptual model integrating biological, physical and chemical distribution mechanisms. Mar. Pollut. Bull. 113, 7-16 https://doi.org/10.1016/j. marpolbul.2016.10.002

Vianello, a., Boldrin, a., Guerriero, P., Moschino, V., Rella, R., Sturaro, a., Da Ros, L., 2013. Microplastic particles in sediments of Lagoon of Venice, Italy: first observations on occurrence, spatial patterns and identification. Estuar. Coast Shelf Sci. 130, 54-61 https://doi.org/10.1016/j.ecss.2013.03.022.

Von Moos, N., Burkhardt-Holm, P., Koehler, A., 2012. Uptake and E ff ects of microplastics on cells and tissue of the blue mussel Mytilus edulis L. After an experimental exposure. Environ. Sci. Technol. 46, 327-335 https://doi.org/10.1021/ es $302332 \mathrm{w}$

Watts, A.J.R., Lewis, C., Goodhead, R.M., Beckett, S.J., Moger, J., Tyler, C.R., Galloway, T.S., 2014. Uptake and retention of microplastics by the shore crab Carcinus maenas. Environ. Sci. Technol. 48, 8823-8830 https://doi.org/10.1021/ es501090e.

Watts, A.J.R., Urbina, M. a., Corr, S., Lewis, C., Galloway, T.S., 2015. Ingestion of plastic microfibers by the crab Carcinus maenas and its effect on food consumption and energy balance. Environ. Sci. Technol. 49, 14597-14604 https://doi.org/ 10.1021 acs.est.5b04026.

Wong, J.X.W., Van Colen, C., Airoldi, L., 2015. Nutrient levels modify saltmarsh responses to increased inundation in different soil types. Mar. Environ. Res. 104, 37-46 https://doi.org/10.1016/j.marenvres.2014.12.003.

Wright, S.L., Thompson, R.C., Galloway, T.S., 2013. The physical impacts of microplastics on marine organisms: a review. Environ. Pollut. 178, 483-492 https:// doi.org/10.1016/j.envpol.2013.02.031

\section{H 2 \& \%OUE}

Only $5.5 \%$ of crabs contained microplastic in their gastrointestinal tracts, with a high quantitative variability between individuals. Enzymatic and $\mathrm{KOH}$ digestion methods did not cause any visible alterations of microfibres. 